Cepel, M., Kljucnikov, A., Kozubikova, L., \& Krajcik, V. (2019). Local Currency as a Mean of Regional Competitiveness Development. Journal of Competitiveness, 11(4), 22-39. https://doi.org/10.7441/ joc. 2019.04 .02

\title{
LOCAL CURRENCY AS A MEAN OF REGIONAL COMPETITIVENESS DEVELOPMENT
}

\section{- Martin Cepel, Aleksandr Kljucnikov, Ludmila Kozubikova, Vladimir Krajcik}

\begin{abstract}
This article aims to define and analyze important factors of the introduction of a local currency. The research was carried out in the Cieszyn Silesia region. A questionnaire was prepared and distributed among the employees of both public and private companies in the region and filled in by 422 respondents. Advanced data analysis methods were used to evaluate the questionnaire: contingency tables, absolute and relative species abundance, the Pearson's chi-squared test, along with a standard score (Z-score). Respondents' attitudes towards introducing the local currency led to some interesting results. Most respondents know the term "local currency," but only one third of them are able to interpret this term correctly. $65 \%$ of the respondents are familiar with the term "digital currency," but only $11 \%$ of them have trust in the concept. According to the received answers, the credibility of digital currency can be increased by it being ensured by trustworthy subjects. Three out of four respondents predict that the introduction of digital currency would significantly support regional producers and service providers. These results are used as the information base for assessments regarding the types of employee benefits on offer by major employers in the region along with cooperating institutions of the public non-profit sector, as well as for an academic discussion on the suitability of the local currency in the Czech Republic and its impact.
\end{abstract}

Keywords: Local currency, digital currency, Cieszyn Silesia region, competitiveness JEL Classification: L29, M29

Received: August, 2019

1st Revision: October, 2019

Accepted: October, 2019

\section{INTRODUCTION}

Changes regarding economic development can cause crises in national currencies. Traditional money has been "taken aback" by the development of the global market and its digitalization. The biggest problem is that large amounts of national currencies are accumulated by the major players in the markets, which leads to widening of the social divide - multinational corporations are getting richer with this allowing them to dictate terms to the wider economy, thus less wealthy or poor people become poorer and the middle class slowly disappears. 
Among the main motives for introducing a local currency - Community Currency ("CC") - is an effort to complete the necessary social functions that national and multinational currencies lack; e.g. resolving unemployment and other social problems. Since local currencies may circulate in closed local systems several times faster and produce a much higher profit, they appear to be more efficient than national currencies in dealing with these problems (The Centre of Regional Synergy).

Local currencies refer generally to the community currencies established by local non-profit organizations that follow the goal of satisfying needs that are not met by market activities or public services. Local currencies development brings interesting opportunities for the segment of small and medium-sized enterprises, which is an extremely important part of national economies (Cepel et al., 2018; Ključnikov et al., 2017; Vojtovič, 2016). Considering criticism of local currency, it is important to mention from the start that the replacement of a national currencies is not the goal of establishing and using local currencies.

\section{LITERATURE BACKGROUND}

Many researchers have attempted to set a typology of Community, Complementary and Local Currency Systems ("CCs") since CCs appeared at the beginning of the 1980s almost forty years ago. According to Blanc (2011), there is not one single common typology generally shared by academics and activists. One of the reasons for this fact can be seen in the non-uniform understanding and defining the terms "complementary currency," "community currency" along with other terms describing these phenomena. The authors here attempt to classify and categorize CCs in a way that looks toward future developments in a way that also encapsulates the diverse historical trends in their development.

A simplified sketch of the time evolution of individual generations of CCs highlights four basic groups of monetary models, i.e. four generations (G1-G4). The design of the systems initially introduced in the 1930s sought to promote the circulation of money and limit its accumulation (e. g Wörgl). The 1950s brought to life a local voucher system experiment (e.g. France, Argentina), the special currencies of which were used in Barter Clubs. In the early 1980s, there was a new wave associated with the introduction of the LETS (Local Exchange Trading System) in Canada. The motive for introducing LETS was related to the massive unemployment that was stemming from the collapse of local industry. The motive for introducing the LETS model, which has gradually spread around the world, is usually related to such emergencies as wars, currency crises, solvency problems, with LETS disappearing when economic and monetary conditions improve or when public authorities prohibit their circulation (e.g. Wäea, Valor and Wörgl ended this way). Originally, local currencies were mainly invented as alternative and temporary solutions, while newly emerging local currencies are understood as complementary and enduring solutions (Fare \& Ahmed, 2017).

Similarly, Blanc (2011) distinguishes four generations of CCs. He points out that time is not the only factor influencing the exchange value of a currency, but it is also necessary to consider currency inconvertibility as a crucial point. According to the author, the classification described above is flexible enough. G1 appeared in the 1980s and included LETS, while trueque was in- 
stituted in Argentina, with money issued before the exchange and as a precondition of it. These systems had been very dynamic up to the second half of the 1990s. The G1 systems aimed to strengthen and consolidate social inclusion, create social ties and provide its members with improved means toward solvency. People exchanged the necessary goods and services for other goods or services without using physical currency. G2 at the end of the 1980s included Timebanks - purely community currencies built on the central criterion of multilateral reciprocity. The G2 systems aimed to promote exchanges of services with a variety of social, community and political objectives as well as increasing solidarity among individuals. G3 started with the Ithaca Hour in 1991, which was derived from the LETS model. During the 2000s, systems emerged such as the Chiemgauer in Germany, Palmas in Brazilia and Berk Shares in the US. In contrast to the first and second generations, G3 was backed by national currency reserves through the convertibility principle. The G3 schemes aimed to transform and relocate the energy, health, agriculture and industry sectors to make them more sustainable and improve their ability to cope with putative climate change. The G4 schemes are constituted by multiplex projects in which local authorities play a major role, and they focus on environmental issues more than ever before. Because of multiplexity, these projects are costly and difficult to engineer, and require a complex governance (e.g. French SOL, NU project of EU). G4 usually appears in the form of electronic currency requiring the use of smart cards and tablets. There is an increasing concern toward the environment compared to the previous systems.

It is important to note that newly emerging generations of monetary systems do not necessarily terminate nor reject the former generations. On the contrary, they often transform them as innovations bringing new impulses. This classification shows that each generation of monetary systems pursues a specific, dominant goal or orientation, and develops the monetary system in a way adjusted to that goal.

In general, local currencies pursue the following objectives. First, to support the local economy and help unemployed people participate in productive activities by using their skills and increasing their self-esteem (Sanz, 2016; Michel \& Hudon, 2015; Kichiji \& Nishibe, 2008; Collom, 2005; 2007; Williams et al., 2001; Brenes, 2011). Sanz (2016) augments this explanation by indicating how the main motivations to use the local currency is the contribution to the society, increasing local business sales and promotion, and increasing sustainability in the locality. Another objective is to integrate new production and consumption processes while strictly respecting social and environmental standards. A final but also important aim concerns strengthening of the social use of money and citizens' involvement in economic and monetary decision-making (Ruddick et al., 2015; Seyfang, 2015).

It is obvious from the above that most authors emphasize both the economic and social impact of local currencies depending on the type of CCs generation. Michel \& Hudon (2015) suggest in detail that the implementation of a community currency seeks to improve the skills and networking of the community, which in turn aids jobseekers in securing employment. The local currency also helps to increase local consumption and economic growth to facilitate the search for jobs; to increase sales of local commodities and to foster local businesses; to increase mutual understanding and social bonding as well as general community living standards, and to promote localization. 
Lopaciuk-Gonczaryk (2019) found that social development was enhanced by using LETS, which helped local people to meet together more often in various ways. Cooperative behavior increased and people became more dependent on the local currencies, which also increased the involvement in local community development and people's motivation to transact locally. The results of Sanz (2016) suggest that local currency improves community participation and social bonding between the users, and using local currency improves the local community in terms of production and economic development. It also increases mutual trust and helps to develop the enhanced networking. The local currency helps to spend more in the local community which helps to reduce poverty. People using the local currency were satisfied, and they would like to use it in the future as well. Similarly, Kichiji \& Nishibe (2008) argue that the local currency increases the sales of goods and services and increases people's cooperation, and creates mutual understanding. It helped to increase the use of locally available goods and services, and to reduce unemployment and enhance economic sustainability in the community.

The advantages of the community currency in Grecia county in Costa Rica, named as "UDIS" in 2007, are described by Brenes (2011). He found that the currency helped the businesses to pay out the worker and increased the spending of the workers within the businesses. It also increased a local production and stimulated sales; empowered the community spending behavior while the banking system was poor. The currency made it easier for businesses to use local resources more effectively and become more resilience in their community products. Ruddick, Richards \& Bendell (2015) argue that the project of local currency Bangla-Pesa in 2013 was successful as it reduced the dependency on the national currency and increased local sales. It can increase the living conditions of the community and reduce poverty, as the ideal types of community, complementary and local currencies let the possibility of combinations being able to analyze concrete forms of non-national and not-for-profit currencies (Blanc, 2011).

Among the main problems associated with the introduction of local currencies, there are funding problems, whether from the local authorities', the state's or the companies' point of view, lack of awareness of their existence, lack of knowledge (especially in the case of digital currencies), poor local currencies credibility. Among the authors who evaluate the local currency impact mostly negatively, resp. emphasize the problems associated with its implementation, there are, e.g. Marshall \& O’Neill, 2018; Schroeder (2015); Scott Cato \& Suarez (2012). This involves articles that are mainly concerned with an unconfirmed increase in employment or not raised region economic level support by introducing the local currency, resp. articles pointing out problems related to its implementation, which mainly concern the financing of local currency systems, lack of project financial managers, insufficient involvement of municipalities and companies, lack of professional and technical knowledge.

Concretely, Marshall \& O’Neill (2018) searched the Bristol pound and found that this currency did not have any influence on the local procurement behavior of the enterprises. The authors argue that most of the products were purchased outside of the Bristol pound area and hence the Bristol pound mechanism failed to enhance the local production and consumption mainly due to the external supplier, as they were not accepting the Bristol pound although it was fully convertible to Sterling/Pound. The main barriers for the Bristol pound were due to the political influence (it is difficult to have total control over the local currency), capital mobility, free trade, 
corporate power, banks, money and public goods and cultural barriers (not all the people in the community are open to accept the Bristol pound due to the lack of trust).

According to Kichiji \& Nishibe (2008), the challenges the currency faced is the lack of trading partners and not all the vendors were open to accept it. The main barriers set by Williams et al. (2001) are found to be the following: lack of promotion and lack of publicity of the LETS; people did not know whether they can contribute through their skills and can engage in the system and whether it exists in other communities; lack of trust and coordination of the system; lack of support from the government. Ruddick et al. (2015) argued that the main challenges connected to the local currency Bangla-Pesa in 2013 were the lack of awareness of the people, as local people did not know much about how to use it and a result-the circulation of this currency was limited.

As it is clear from the explanation above, in each effort to introduce the local currency, there are different traps, which arose from the listed restrictions and are related mainly to the local currency's credibility (trustworthiness) and the awareness and knowledge of its use. Emerging currencies need to be accepted as a means of payment by the major goods and services suppliers such as banks and local authorities. Based on the critical research on the articles about a local currency, we have found out that no research has been carried out on the subject neither for the studied region nor for the Czech Republic as such. There is a research gap that is apparent, and it should be partly filled with the following results of our research.

\section{AIM, METHODOLOGY AND METHODS}

The aim of the article is to define and analyze important factors of the local currency introduction. The partial aim of the article is to find out whether the respondents in different age groups or different job positions have the same attitudes towards the introduction of the local (community) currency. The respondents were employees in the Cieszyn Silesia region.

The following hypotheses related to the very aim of the article have been formulated based on the literature review:

H1: The age and job position of the respondent influence his/her attitudes to the questions concerning the introduction of the local (community) currency in the Cieszyn Silesia region.

H2: More than $50 \%$ of respondents think that the biggest employers in the region should be more supportive of regional producers and service providers.

H3: More than $50 \%$ of respondents assume that a secured digital currency is an appropriate way for providing employers with additional benefits.

The aim of the questionnaire survey was to determine whether employees are interested in introducing the local community currency in the Cieszyn Silesia region. The questionnaire was distributed to employees of all major regional public and private employers. 422 employees (respondents) participated in the questionnaire survey. For the statistical evaluation, 413 (100\% of respondents) completed questionnaires were used, 9 questionnaires were taken from the evaluation due to a badly completed questionnaire or incomplete information (misunderstood question, failure to provide necessary data). The questionnaire contained 22 questions. The questionnaire was divided into two parts: selected social and demographic characteristics (6 questions). The 
first part of the questionnaire focused on the structure of the employees: gender, age, duration of employment, marital status, job position of the employee and the region where the employee resides. The second part dealt with the respondents' attitudes to the introduction of the local (community) currency in the region (16 questions). For writing the article, all 6 questions from the first part and 7 questions from the second part were evaluated. The questionnaire was distributed to the respondents in a paper form. Then, an online form of the questionnaire was prepared for a clearer processing of the questionnaire survey:

https://docs.google.com/forms/d/e/1FAIpQLSeIqAWJI4oFHbzidJn19X_BwPKYLq3BxYVeuCj7npIdYdPyRA/viewform

According to the formulated hypotheses, the following questions were articulated in the questionnaire survey: do you know the term local (community) currency? (Yes, No); do you trust digital currencies? (Yes, Don't know, No); would you trust a DIGITAL local currency that is secured by a trusted entity (bank, state, significant large private enterprise) and whose exchange rate is firmly tied to the Czech koruna? (Yes, Almost yes, Don't know, No); would you trust a PAPER local currency that is secured by a trusted entity (bank, state, significant large private enterprise) and whose exchange rate is firmly tied to the Czech koruna? (Yes, Almost yes, Don't know, No); do you agree that both major regional employers and your company should provide greater support to the regional producers and service providers? (Yes, Don't know, No); do you think that an ensured and trusted local currency, which is valid only in the given region, is an appropriate form of support for the regional producers and service providers? (Yes, Don't know, No); would you agree your employer provides you with additional employee benefits transferring a local secured digital currency to your special account? (Yes, Don't know, No).

The following descriptive statistical instruments were used to assess the formulated hypotheses that were then used to apply the Pearson's chi-squared test method and Z-score test method. Then we used statistical methods such as absolute abundance and simple sorting of the selected criterion (statistical signs - age and job position of the respondent). In the simple sorting method, attention was paid to the expression of the relative abundance. Other techniques were for the classification according to two statistical features, the dependence between qualitative plural statistics (contingency table, contingency intensity). The intensity of contingency was evaluated by the Pearson coefficient of contingency based on square contingency. The statistical hypotheses were evaluated using the above-mentioned Pearson's chi-squared test method and Z-score test method. The individual hypotheses were verified at a $5 \%$ level of statistical significance. The resulted $\mathrm{p}$-value of less than 0.05 led to the rejection of the hypothesis on the independence of the variables. The $\mathrm{Z}$-score test method was used to identify significant statistical differences between the selected groups of respondents on the selected criterion (age and job position). Pvalue of the normal (standardized) distribution was used o evaluate the $Z$-score parameters. The conditions for performing the Z-test (normal distribution of the statistical character and large sample size) have been fulfilled. All calculations required to evaluate the statistical hypotheses were performed in the SPSS Statistics analysis software.

The structure of the respondents was as follows: gender - men $358(86.7 \%)$ and women 55 (13.3\%); age - before age 3552 (12.6\%), age 35-49 193 (46.7\%) and age 50 and over 168 (40.7\%); assignment in the company - less than 5 years $53(12.8 \%)$, from 5 to 10 years $41(9.9 \%)$ and more 
than 10 years $(319$ (77.3\%); marital status - single $69(16.7 \%)$, married $276(66.8 \%)$ and divorced 68 (16.5\%); job description - administrative 62 (15.0\%), manager 26 (6.3\%), production (workers) $274(66.4 \%)$, manufacturing leader position $36(8.7 \%)$ and others 15 (3.6\%); permanent residence - Třinec 204 (49.4\%), Jablunkov 39 (9.4\%), Bystřice 29 (7.0\%), Vendryně 20 (4.8\%), Český Těšín 18 (4.4\%), other regions (less than 10 respondents) 103 (24.9\%). While the questionnaire was distributed to the respondents both in paper and online form, significant differences in the results based on the questionnaire type were not detected.

\section{RESULTS}

From the results of the questionnaire survey, it is clear that 219 employees (53\%) know the concept of local currency. On the contrary, up to 194 employees (47\%) do not know the concept of local currency.

Tab. 1 - Understanding the term „local currency”. Source: own research

\begin{tabular}{|c|c|c|c|c|c|c|}
\hline $\begin{array}{l}\text { CRITERION } \\
\text { (C) }\end{array}$ & KLC* & $\begin{array}{l}\text { Age 35-49 } \\
(35+)\end{array}$ & $\begin{array}{l}\text { Age } 50 \text { and } \\
\text { over }(50+)\end{array}$ & $\begin{array}{l}\text { Before age } \\
35(35-)\end{array}$ & $\begin{array}{l}\text { Total sum } \\
\text { (TS) }\end{array}$ & $\begin{array}{l}\text { Z-score } \\
\text { p-value } \\
35+/ 50+ \\
35+/ 35- \\
50+/ 35-\end{array}$ \\
\hline \multirow{3}{*}{ AGE } & No & 89 & 80 & 25 & 194 & 0.4654 \\
\hline & Yes & 104 & 88 & 27 & 219 & 0.5823 \\
\hline & Sum & $193(46.1 \%)$ & $168(47.6 \%)$ & $52(48.1 \%)$ & 413 & 0.9522 \\
\hline $\mathrm{C}$ & KLC* & $\begin{array}{l}\text { Production } \\
(\mathrm{P})\end{array}$ & $\begin{array}{l}\text { Administr. } \\
\text { (A) }\end{array}$ & $\begin{array}{l}\text { Manager } \\
(\mathrm{M})\end{array}$ & Total sum & $\begin{array}{l}\text { Z-score } \\
\text { p-value } \\
\mathrm{P} / \mathrm{A} \\
\mathrm{P} / \mathrm{M} \\
\mathrm{A} / \mathrm{M}\end{array}$ \\
\hline \multirow{3}{*}{$\begin{array}{l}\text { JOB } \\
\text { POSITION }\end{array}$} & No & 142 & 25 & 27 & 194 & 0.0719 \\
\hline & Yes & 132 & 37 & 50 & 219 & 0.0093 \\
\hline & Sum & $274(52 \%)$ & $62(40 \%)$ & $77(35 \%)$ & 413 & 0.5222 \\
\hline
\end{tabular}

*Knowledge of the local currency

The chi-squared test did not show statistically significant differences according to the number of employees of different age categories (Chi-square $=0.111$; $\mathrm{p}$-value $=0.946$ ), but according to the job position - yes $($ Chi-square $=8.074$; $\mathrm{p}$-value $=0.017)$. The $Z$-score test values showed that there are no statistically significant differences in the "NO" response among the age groups. (This means that there are no differences in the "YES" answers either). The Z-score test values showed that there are statistically significant differences in the "NO" response among different job positions. Managers (M) statistically significantly less responded "NO" (35\%) compared to the production workers (P: $52 \%$ ). According to the structure of the existing responses, we can 
say that it shows that managers (M) statistically significantly more responded "YES" compared to the workers in production $(\mathrm{P})$.

The results of the questionnaire survey show that 45 employees $(10.9 \%)$ trust digital currencies; 221 employees (53.5\%) do not trust digital currencies and 147 employees (35.6\%) have not taken a stand on the credibility of digital currencies.

Tab. 2 - Credibility for digital currencies. Source: own research

\begin{tabular}{|c|c|c|c|c|c|c|}
\hline $\begin{array}{l}\text { CRITERION } \\
\text { (C) }\end{array}$ & KLC* & $\begin{array}{l}\text { Age } 35-49 \\
(35+)\end{array}$ & $\begin{array}{l}\text { Age } 50 \text { and } \\
\text { over }(50+)\end{array}$ & $\begin{array}{l}\text { Before } \\
\text { age } 35 \\
(35-)\end{array}$ & $\begin{array}{l}\text { Total } \\
\text { sum (TS) }\end{array}$ & $\begin{array}{l}Z \text {-score } \\
\text { p-value } \\
35+/ 50+ \\
35+/ 35- \\
50+/ 35-\end{array}$ \\
\hline \multirow{4}{*}{ AGE } & No & 100 & 100 & 21 & 221 & 0.0949 \\
\hline & Yes & 24 & 12 & 9 & 45 & 0.3628 \\
\hline & Don't know & 69 & 56 & 22 & 147 & 0.0293 \\
\hline & Sum & $193(36 \%)$ & $168(33 \%)$ & $52(42 \%)$ & 413 & \\
\hline $\mathrm{C}$ & KLC* & $\begin{array}{l}\text { Production } \\
(\mathrm{P})\end{array}$ & $\begin{array}{l}\text { Administr. } \\
\text { (A) }\end{array}$ & $\begin{array}{l}\text { Manager } \\
(\mathrm{M})\end{array}$ & $\begin{array}{l}\text { Total } \\
\text { sum }\end{array}$ & $\begin{array}{l}\text { Z-score } \\
\text { p-value } \\
\mathrm{P} / \mathrm{A} \\
\mathrm{P} / \mathrm{M} \\
\mathrm{A} / \mathrm{M}\end{array}$ \\
\hline \multirow{4}{*}{$\begin{array}{l}\text { JOB } \\
\text { POSITION }\end{array}$} & No & 156 & 25 & 40 & 221 & 0.7490 \\
\hline & Yes & 23 & 6 & 16 & 45 & 0.0022 \\
\hline & Don't know & 95 & 31 & 21 & 147 & 0.0751 \\
\hline & Sum & $274(8 \%)$ & $62(10 \%)$ & $77(21 \%)$ & 413 & \\
\hline
\end{tabular}

*Knowledge of the local currency

The chi-squared test did not show statistically significant differences according to the number of employees in different age categories (Chi-square $=8.367 ; \mathrm{p}$-value $=0.079)$, but according to the job position - yes $($ Chi-square $=16.391 ; \mathrm{p}$-value $=0.002)$. The $\mathrm{Z}$-score test values showed that there are statistically significant differences in the "YES" response among different age groups. The respondents before age 35 statistically significantly more (17\%) trust digital currencies than respondents aged 50 and over (only 7\% answered "yes"). The Z-score test values showed that there are statistically significant differences in the "YES" response among different job positions. The managers (M) statistically significantly often responded "YES" (21\%) compared to the production workers (P: 8\%). This means that they trust digital currencies more.

The results of the questionnaire survey show that 46 employees $(11.1 \%)$ would trust such a digital currency; 89 employees $(21.5 \%$ ) would rather trust such a digital currency and 145 employees $(35.4 \%)$ would not trust such a digital currency. 
Tab. 3 - Credibility for the digital currency ensured by trustworthy subjects. Source: own research

\begin{tabular}{|c|c|c|c|c|c|c|}
\hline $\begin{array}{l}\text { CRITE- } \\
\text { RION (C) }\end{array}$ & KLC* & $\begin{array}{l}\text { Age } 35-49 \\
(35+)\end{array}$ & $\begin{array}{l}\text { Age } 50 \text { and } \\
\text { over }(50+)\end{array}$ & $\begin{array}{l}\text { Before age } \\
35(35-)\end{array}$ & $\begin{array}{l}\text { Total } \\
\text { sum (TS) }\end{array}$ & $\begin{array}{l}\text { Z-score } \\
\text { p-value } \\
35+/ 50+ \\
35+/ 35- \\
50+/ 35-\end{array}$ \\
\hline \multirow{5}{*}{ AGE } & No & 58 & 73 & 14 & 145 & 0.0001 \\
\hline & Yes & 27 & 14 & 5 & 46 & 0.2585 \\
\hline & Rather yes & 49 & 20 & 20 & 89 & 0.0001 \\
\hline & Don't know & 59 & 61 & 13 & 133 & \\
\hline & Sum $(\%)$ & $193(39)$ & $168(20)$ & $52(48)$ & $413(33)$ & \\
\hline $\mathrm{C}$ & KLC* & $\begin{array}{l}\text { Production } \\
(\mathrm{P})\end{array}$ & $\begin{array}{l}\text { Administr. } \\
\text { (A) }\end{array}$ & $\begin{array}{l}\text { Manager } \\
(\mathrm{M})\end{array}$ & $\begin{array}{l}\text { Total } \\
\text { sum }\end{array}$ & $\begin{array}{l}\text { Z-score } \\
\mathrm{p} \text {-value } \\
\mathrm{P} / \mathrm{A} \\
\mathrm{P} / \mathrm{M} \\
\mathrm{A} / \mathrm{M}\end{array}$ \\
\hline \multirow{5}{*}{$\begin{array}{l}\text { JOB POSI- } \\
\text { TION }\end{array}$} & No & 111 & 12 & 22 & 145 & 0.0020 \\
\hline & Yes & 21 & 10 & 15 & 46 & 0.0001 \\
\hline & Rather yes & 38 & 15 & 36 & 89 & 0.0023 \\
\hline & Don't know & 104 & 25 & 4 & 133 & \\
\hline & Sum $(\%)$ & $274(22)$ & $62(40)$ & $77(66)$ & $413(31)$ & \\
\hline
\end{tabular}

*Knowledge of the local currency

The chi-squared test showed statistically significant differences according to the number of employees in different age categories (Chi-square $=25.784$; $\mathrm{p}$-value $=0.0002)$. In this answer, we combined "yes" and "rather yes" answers into one group. We found that the younger age groups statistically significantly more answered "yes" compared to the respondents aged 50 and over. The chi-squared test showed statistically significant differences according to the number of employees in different job position categories (Chi-square $=68.691$; p-value $=0.000$ ). There are statistically significant differences in the "YES + RATHER YES" response among different job positions.

The results of the questionnaire survey show that 59 employees $(14.2 \%)$ would trust the local currency banknotes; 92 employees $(22.3 \%)$ would rather trust the local currency banknotes and 139 employees $(33.7 \%$ ) would not trust the local currency banknotes. 
Tab. 4 - Confidence in the local currency banknotes. Source: own research

\begin{tabular}{|c|c|c|c|c|c|c|}
\hline $\begin{array}{l}\text { CRITE- } \\
\text { RION (C) }\end{array}$ & KLC* & $\begin{array}{l}\text { Age } 35-49 \\
(35+)\end{array}$ & $\begin{array}{l}\text { Age } 50 \\
\text { and over } \\
(50+)\end{array}$ & $\begin{array}{l}\text { Before age } \\
35(35-)\end{array}$ & $\begin{array}{l}\text { Total } \\
\text { sum } \\
\text { (TS) }\end{array}$ & $\begin{array}{l}\text { Z-score } \\
\text { p-value } \\
35+/ 50+ \\
35+/ 35- \\
50+/ 35-\end{array}$ \\
\hline \multirow{5}{*}{ AGE } & No & 61 & 68 & 10 & 139 & 0.0271 \\
\hline & Yes & 29 & 23 & 7 & 59 & 0.8572 \\
\hline & Rather yes & 50 & 27 & 15 & 92 & 0.0950 \\
\hline & Don't know & 53 & 50 & 20 & 123 & \\
\hline & Sum $(\%)$ & $193(41 \%)$ & $168(30 \%)$ & $52(42 \%)$ & 413 & \\
\hline C & KLC* & $\begin{array}{l}\text { Production } \\
\text { (P) }\end{array}$ & $\begin{array}{l}\text { Administr } \\
\text { (A) }\end{array}$ & $\begin{array}{l}\text { Manager } \\
(\mathrm{M})\end{array}$ & $\begin{array}{l}\text { Total } \\
\text { sum }\end{array}$ & $\begin{array}{l}\text { Z-score } \\
\text { p-value } \\
\mathrm{P} / \mathrm{A} \\
\mathrm{P} / \mathrm{M} \\
\mathrm{A} / \mathrm{M}\end{array}$ \\
\hline \multirow{5}{*}{$\begin{array}{l}\text { JOB } \\
\text { POSITION }\end{array}$} & No & 100 & 12 & 27 & 139 & $<0.0001$ \\
\hline & Yes & 31 & 12 & 16 & 59 & 0.0031 \\
\hline & Rather yes & 48 & 24 & 20 & 92 & 0.1835 \\
\hline & Don't know & 95 & 14 & 14 & 123 & \\
\hline & Sum $(\%)$ & $274(29 \%)$ & $62(58 \%)$ & $77(47 \%)$ & 413 & \\
\hline
\end{tabular}

*Knowledge of the local currency

The chi-squared test showed statistically significant differences according to the number of employees in different age categories (Chi-square $=12.635$; $\mathrm{p}$-value $=0.049)$. The respondents before 50 years old statistically significantly answered positively compared to the respondents aged 50 and over. The chi-squared test showed statistically significant differences according to the number of employees in individual job position categories (Chi-square $=27.083$; $\mathrm{p}$-value $=$ 0.000). The $Z$-score test showed that there are statistically significant differences between $P / A$ and $\mathrm{P} / \mathrm{M}$. The production workers statistically significantly less answered the question positively compared to the administrative employees and the managers. The above results show that we can accept the hypothesis H1.

The results of the questionnaire survey show that 307 employees $(74.3 \%)$ preserve their opinion that the company should strongly support regional producers and service providers; 38 employees $(9.2 \%)$ preserve their opinion that the company should not strongly support regional producers and service providers and 68 employees $(16.5 \%)$ have not taken a stand on this question. 
Tab. 5 - Regional producers and service providers support. Source: own research

\begin{tabular}{|c|c|c|c|c|c|c|}
\hline $\begin{array}{l}\text { CRITE- } \\
\text { RION (C) }\end{array}$ & KLC* & $\begin{array}{l}\text { Age } 35-49 \\
(35+)\end{array}$ & $\begin{array}{l}\text { Age } 50 \\
\text { and over } \\
(50+)\end{array}$ & $\begin{array}{l}\text { Before age } \\
35 \text { (35-) }\end{array}$ & $\begin{array}{l}\text { Total } \\
\text { sum } \\
\text { (TS) }\end{array}$ & $\begin{array}{l}\text { Z-score } \\
\text { p-value } \\
35+/ 50+ \\
35+/ 35- \\
50+/ 35-\end{array}$ \\
\hline \multirow{4}{*}{ AGE } & No & 19 & 17 & 2 & 38 & 0.7642 \\
\hline & Yes & 144 & 123 & 40 & 307 & 0.7279 \\
\hline & Don't know & 30 & 28 & 10 & 68 & 0.5961 \\
\hline & Sum & 193 & 168 & 52 & 413 & \\
\hline C & KLC* & $\begin{array}{l}\text { Production } \\
(\mathrm{P})\end{array}$ & $\begin{array}{l}\text { Administr } \\
\text { (A) }\end{array}$ & $\begin{array}{l}\text { Manager } \\
(\mathrm{M})\end{array}$ & $\begin{array}{l}\text { Total } \\
\text { sum }\end{array}$ & $\begin{array}{l}\text { Z-score } \\
\mathrm{p} \text {-value } \\
\mathrm{P} / \mathrm{A} \\
\mathrm{P} / \mathrm{M} \\
\mathrm{A} / \mathrm{M}\end{array}$ \\
\hline \multirow{4}{*}{$\begin{array}{l}\text { JOB } \\
\text { POSITION }\end{array}$} & No & 26 & 7 & 5 & 38 & 0.1585 \\
\hline & Yes & 192 & 49 & 66 & 307 & 0.0060 \\
\hline & Don't know & 56 & 6 & 6 & 68 & 0.2983 \\
\hline & Sum & $274(70 \%)$ & $62(79 \%)$ & $77(86 \%)$ & 413 & \\
\hline
\end{tabular}

*Knowledge of the local currency

The chi-squared test did not show statistically significant differences according to the number of employees in individual age categories (Chi-square $=2.283$; $\mathrm{p}$-value $=0.684$ ). There are no statistically significant differences in the "YES" response within the age groups examined. The chi-squared test showed statistically significant differences according to the number of employees in individual job position categories (Chi-square $=11.006$; $\mathrm{p}$-value $=0.026$ ). The managers statistically significantly often answered the questions "YES" compared to the production workers. We accept the hypothesis $\mathrm{H} 2$.

The results of the questionnaire survey show that 102 employees $(24.7 \%)$ preserve their opinion that of ensured and trusted local currency is an appropriate support for regional producers and service providers; 155 employees (37.5\%) state that the ensured and trusted local currency is not an appropriate support for regional producers and service providers and 156 employees (37.8\%) have not taken a stand on this question. 
Tab. 6 - Suitability of the local currency as a form of support of regional products and services. Source: own research

\begin{tabular}{|c|c|c|c|c|c|c|}
\hline $\begin{array}{l}\text { CRITERION } \\
\text { (C) }\end{array}$ & KLC* & $\begin{array}{l}\text { Age } 35-49 \\
(35+)\end{array}$ & $\begin{array}{l}\text { Age } 50 \\
\text { and over } \\
(50+)\end{array}$ & $\begin{array}{l}\text { Before } \\
\text { age } 35 \\
(35-)\end{array}$ & $\begin{array}{l}\text { Total } \\
\text { sum } \\
\text { (TS) }\end{array}$ & $\begin{array}{l}\text { Z-score } \\
\text { p-value } \\
35+/ 50+ \\
35+/ 35- \\
50+/ 35-\end{array}$ \\
\hline \multirow{4}{*}{ AGE } & No & 72 & 63 & 20 & 155 & 0.0930 \\
\hline & Yes & 55 & 35 & 12 & 102 & 0.4354 \\
\hline & Don't know & 66 & 70 & 20 & 156 & 0.7279 \\
\hline & Sum & $193(28 \%)$ & $168(21 \%)$ & $52(23 \%)$ & 413 & \\
\hline $\mathrm{C}$ & KLC* & $\begin{array}{l}\text { Production } \\
(\mathrm{P})\end{array}$ & $\begin{array}{l}\text { Administr } \\
\text { (A) }\end{array}$ & $\begin{array}{l}\text { Manager } \\
(\mathrm{M})\end{array}$ & $\begin{array}{l}\text { Total } \\
\text { sum }\end{array}$ & $\begin{array}{l}\text { Z-score } \\
\text { p-value } \\
\mathrm{P} / \mathrm{A} \\
\mathrm{P} / \mathrm{M} \\
\mathrm{A} / \mathrm{M}\end{array}$ \\
\hline \multirow{4}{*}{$\begin{array}{l}\text { JOB } \\
\text { POSITION }\end{array}$} & No & 102 & 24 & 29 & 155 & 0.0128 \\
\hline & Yes & 53 & 21 & 28 & 102 & 0.0017 \\
\hline & Don't know & 119 & 17 & 20 & 156 & 0.7566 \\
\hline & Sum & $274(19 \%)$ & $62(34 \%)$ & $77(36 \%)$ & 413 & \\
\hline
\end{tabular}

*Knowledge of the local currency

The chi-squared test did not show statistically significant differences in terms of the number of employees in individual age categories (Chi-square $=3.548$; $\mathrm{p}$-value $=0.470)$, with no statistically significant differences in the "YES" response within the age groups examined. The chi-squared test showed statistically significant differences according to the number of employees in each job position category (Chi-square $=16.486$; $\mathrm{p}$-value $=0.0024)$. There are statistically significant differences in the "YES" response between the production workers and the administrative employees, resp. managers.

The results of the questionnaire survey show that 135 employees $(32.7 \%)$ would agree with the employer providing additional employee benefits in the ensured local digital currency form; 180 employees $(43.6 \%)$ would not agree with the employer providing additional benefits in the local digital currency form, and 98 employees $(23.7 \%)$ did not take a stand on this question. 
Tab. 7 - Additional employee benefits in the local currency form. Source: own research

\begin{tabular}{|c|c|c|c|c|c|c|}
\hline $\begin{array}{l}\text { CRITE- } \\
\text { RION (C) }\end{array}$ & KLC* & $\begin{array}{l}\text { Age } 35-49 \\
(35+)\end{array}$ & $\begin{array}{l}\text { Age } 50 \\
\text { and over } \\
(50+)\end{array}$ & $\begin{array}{l}\text { Before age } \\
35(35-)\end{array}$ & $\begin{array}{l}\text { Total } \\
\text { sum } \\
\text { (TS) }\end{array}$ & $\begin{array}{l}\text { Z-score } \\
\text { p-value } \\
35+/ 50+ \\
35+/ 35- \\
50+/ 35-\end{array}$ \\
\hline \multirow{4}{*}{ AGE } & No & 84 & 80 & 16 & 180 & 0.5419 \\
\hline & Yes & 62 & 49 & 24 & 135 & 0.0601 \\
\hline & Don't know & 47 & 39 & 12 & 98 & 0.0232 \\
\hline & Sum & $193(32 \%)$ & $168(29 \%)$ & $52(46 \%)$ & 413 & \\
\hline $\mathrm{C}$ & KLC* & $\begin{array}{l}\text { Production } \\
\text { (P) }\end{array}$ & $\begin{array}{l}\text { Administr } \\
\text { (A) }\end{array}$ & $\begin{array}{l}\text { Manager } \\
(\mathrm{M})\end{array}$ & $\begin{array}{l}\text { Total } \\
\text { sum }\end{array}$ & $\begin{array}{l}\text { Z-score } \\
\mathrm{p} \text {-value } \\
\mathrm{P} / \mathrm{A} \\
\mathrm{P} / \mathrm{M} \\
\mathrm{A} / \mathrm{M}\end{array}$ \\
\hline \multirow{4}{*}{$\begin{array}{l}\text { JOB } \\
\text { POSITION }\end{array}$} & No & 128 & 24 & 28 & 180 & 0.0058 \\
\hline & Yes & 71 & 27 & 37 & 135 & 0.0002 \\
\hline & Don't know & 75 & 11 & 12 & 98 & 0.5961 \\
\hline & Sum & $274(26 \%)$ & $62(44 \%)$ & $77(48 \%)$ & 413 & \\
\hline
\end{tabular}

*Knowledge of the local currency

The chi-squared test did not show statistically significant differences in terms of the number of employees in individual age categories (Chi-square $=6.187$; $\mathrm{p}$-value $=0.186$ ). The Z-score test values showed that there are statistically significant differences in positive responses of the employees aged before 35 and the employees aged 50 and above. The chi-squared test showed statistically significant differences according to the number of employees in each job position category $($ Chi-square $=18.143 ; \mathrm{p}$-value $=0.001)$. The $\mathrm{Z}$-score test showed that there are statistically significant differences in the answers between $\mathrm{P} / \mathrm{A}$ and $\mathrm{P} / \mathrm{M}$. The managers $(\mathrm{M})$ and the administrative employees (A) statistically significantly often responded "YES" compared to the production workers. We therefore reject hypothesis $\mathrm{H} 3$.

\section{DISCUSSION}

Our literature research has shown that the implementation of the local currency is primarily aimed at increasing the economic benefits of the region. Higher employment is the goal, i.e, the greater involvement of the currently unemployed in the economic life of the region and strengthening social links between individual entities.

The research carried out in the Cieszyn Silesia region revealed that the term local currency is known to most respondents (approx. half $-53 \%$ ), but only one third of them can interpret its meaning correctly. At the same time, the respondents believe that regional producers and service providers need to be supported (almost three of the four surveyed employees $-75 \%$ ), but not everyone is convinced that the local currency is the best-suited solution for this purpose $(25 \%$ are 
convinced). It can be assumed that the establishment of the local currency in the region primarily pursues the economic objective of increasing the economic level and welfare of the Cieszyn Silesia region. The positive consequence of the regional currency implementation is confirmed by the conclusions of Sanz, 2016; Michel \& Hudon, 2015; Kichiji \& Nishibe, 2008; Collom, 2007; Williams et al., 2001; Brenes, 2011. Similarly, Wheatley et al. (2011) as well as other researchers have examined the economic and social benefit of Calgary dollars which was launched in Calgary, Canada as a community currency in 1996 as a digital currency to improve the economic and social condition of the people within the community. The aim was fulfilled, i.e. the demand for goods and services increased as well as social bonding between people and the business enterprises. Another case showing the positive impacts of a local currency came with a system launched in Argentina in paper form in results introduced by Colacelli et al. (2005), who has suggested that the local currency helped the people sell their products, which would not have been possible without the local currency, as the national currency was limited during the crisis. Overall, the paper shows that the use of local currency increased the GDP of the country by $0.6 \%$ during the recession, a result which would not have been possible without the local currency.

On the other hand, some authors point to the unproven positive economic impacts of the local currency, e.g. Aldridge and Patterson (2002) examined the economic impact of a LETS in West London named "Hounslow LETS," which was launched in 1994. They found that the economic benefit of the LETS was minimal, and the rate of unemployment had not decreased and the economic base of the community has not increased. There was a lack of trust between the trading partners, as they did not know each other; a lack of project management was demonstrated as a factor, as the LETS did not get enough funding from the government. Also, the cost of engaging in the project was expensive for the user. In addition, Schroeder (2015) points to a lack of external funding as the main financial problem faced by the local currency project. At the same time, it has also been found that there is a lack of financial administrators who are able manage the program, and there are high transaction costs for the user of the local currency. Similary, studies by both Mashall \& O’Neill (2018) and Kichiji \& Nishibe (2008) found no evidence of an increase in the region's economic benefits due to the local currency.

Even though a relatively small proportion of respondents believe explicitly that the local currency is suitable for supporting regional producers and service providers, i.e. they do not reject this form as an employee benefit ( $33 \%$ agreed with this option). On the other hand, there is the problem of the credibility of the local currency, as only $11 \%$ of the surveyed employees trust the local currency (their credibility would increase if the local currency was ensured). Specifically, $65 \%$ of the surveyed employees are acquainted with the concept of digital currency. In terms of age, young people (under 35) are more trustworthy in the digital currency as are those with a higher position, i.e. managers. Younger people are more familiar with the use of new technologies (including, for example, internet banking, online purchases, etc.) and their use is a common part of their everyday life as opposed to the older generation, which often faces prejudices about the higher riskiness of these forms of payments and types of technology. The finding of support for local currency implementation mainly by young people is, therefore, not surprising.

The results of the local currency credibility problem merely confirm this problem as fundamental in terms of local currency implementations, e.g. other research, e.g. Josavac (2017) has 
indicated both the positive and negative side of community digital currencies. The researcher found that the local currency had improved the social flexibility in buying and selling goods and services but on the other hand, technologies based on local currencies are riskier than those based on a paper-based currency due to risk of hacking and technological faults. Consumers are less protected in the local currency system, with that uncertainty negatively affecting their financial well-being.

To conclude, based on the most opinions of authors enhancing the positive economic and social impact of a local currency for the region, it can be assumed that the implementation of the local currency in the Cieszyn Silesia region would support local producers and service providers; could decrease unemployment, as well as create social bonding among the enterprises and inhabitants of the region. Nevertheless, the currency must be credible (it must be insured by a credible subject) and people must be familiar with the way the local currency is used.

\section{CONCLUSION}

The main aim of this article is to define and analyze important factors of the implementation of a local currency, with a supplementary goal of determining whether the respondents of different age groups or different job positions have the same attitudes towards the introduction of such currency. The research and formulated results are based on a questionnaire survey focused on employees of the Cieszyn Silesia region.

The obtained results brought the following findings. Most respondents in the surveyed region $(53 \%)$ are familiar with the term local currency, and statistically significant differences were found only in case of job position, where managers are more familiar with the term than the production workers. Regarding the credibility of a local currency, it was found that only $11 \%$ of the respondents trust the local currency, with statistically significant differences again found in relation to job position, i.e. credibility is higher among managers compared to manufacturing workers. In relation to the local currency form, there appears to be a slightly higher credibility regarding the paper form compared to the digital form, while more young respondents (aged be-

fore 50) compared to the older respondents expressed a positive opinion regarding the credibility of both digital and paper forms.

A quarter of the respondents believe that an uninsured and secured local currency is an appropriate support mechanism for regional producers and service providers. 33\% of respondents would welcome the option of employee benefits in the form of an ensured local digital currency provided by employers, with a statistically more positive attitude from the administrative employees and managers compared to the production workers.

It was also demonstrated that most of the respondents (74.3\%) are of the opinion that their employers should strongly support regional producers and service providers, and this potential support may be a source of regional development financed from the private sector of the economy. An initial lower level of support $(24.7 \%)$ for using the local currency as an appropriate mean of support for regional producers and service providers shows that the introduction of this approach will not be easy, but due to the fact that $37.8 \%$ of respondents have not taken a stand on this question, the possibility remains that the positive number could increase. 
Despite the regional nature of the research, we believe that the results may be beneficial in view of the hitherto unrealized research on the introduction of the local currency in the Cieszyn Silesia region, with its practical application as an information base in debates regarding the type of employee benefits the major employers in the region and cooperating institutions of the public non-profit sector can offer, as well as for an academic discussion on the suitability of a local currency in the Czech Republic and its impact. We assume that the issue of the local currency in the examined region will be subject to further evaluation based on the results obtained from the conducted research concerning other factors and issues that were not evaluated in this article.

The limitations of our research are mainly connected with its regional focus on employees only in the Cieszyn Silesia region of the Czech Republic. Nevertheless, the results achieved are clearly statistically significant. Our further research activities will be focused on a survey of the opinions of regional producers and service providers on the currency issue, with the identification of ways to increase their willingness to accept a local currency as well as on the formulation of an hypotheses for the identification of potential ways of using the local currency as a mean of regional competitiveness development.

Acknowledgements

TAČR project TL02000562: Research on the potential of introducing a local currency for sustainable development of the territory.

\section{References}

1. Aldridge, T. J., \& Patterson, \& A. (2002). LETS get real: constraints on the development of Local Exchange Trading Schemes. Area, 34 (4), 370-381.

2. Blanc, J. (2011). Classifying "CCs": Community, complementary and local currencies'types and generations. International Journal of Community Currency Research, 15 (4), 4-10. http:// dx.doi.org/10.15133/j.ijccr.2011.013

3. Brenes, E. (2011). Complementary currencies for sustainable local economies in Central America. International Journal of Community currency research, 15 (1), 32-38. http://dx.doi. $\operatorname{org} / 10.15133 /$ j.ijccr.2011.018

4. Cepel, M., Stasiukynas, A., Kotaskova, A., \& Dvorsky, J. (2018). Business Environment Quality Index in the SME Segment. Journal of Competitiveness, 10 (1), 21-40. http://dx.doi. org/10.7441/joc.2018.02.02

5. Colacelli, M., \& Blackburn, D. (2005). Secondary currency: An empirical Analysis. Journal of Monetary Economics, 56 (3), 295-308. https://dx.doi.org/10.1016/j.jmoneco.2009.02.002

6. Collom, E. (2007). The Motivations, Engagement, Satisfaction, Outcomes, and Demographics of Time Bank Participants: Survey Findings from a U.S. System. International Journal of Community Currency Research, 11 (1), 36-83. http://dx.doi.org/10.15133/j. ijccr.2007.004

7. Fare, M., \& Ahmed, P. O. (2017). Complementary Currency Systems and Their Ability to Support Economic and Social Changes. Development and Change, 48 (5), 847-872. https:// dx.doi.org/10.1111/dech.12322 
8. Josavac, M. (2017). The bright and the dark side of virtual currencies recent development in regulatory framework. Journal of Community Currency Research, 21 (2), 1-18. http://dx.doi. $\operatorname{org} / 10.15133 /$ j.ijccr.2017.005

9. Kichiji, N., \& Nishibe, M. (2008). Network analysis of the circulation flow of community currency. Evolutionary and Institutional Economics Review, 4 (2), 267-300. https://dx.doi. org/10.14441/eier.4.267

10. Ključnikov, A., Kozubíková, L., \& Sopková, G. (2017). The Payment Discipline of Small and Medium-Sized Enterprises. Journal of Competitiveness, 9 (2), 45-61. http://dx.doi. org/10.7441/joc.2017.02.04

11. Lopaciuk-Gonczaryk, B. (2019). Social Capital formation through a Polish LETS: Challenging the presumed merits of local currencies. Ecological Economics, 158 (3), 75-87. https://dx.doi.org/10.1016/j.ecolecon.2018.12.004

12. Marshall, A. P., \& O’Neill, D. W. (2018). The Bristol pound: A tool for localization? Ecological Economics, 146 (1), 273-281. http://dx.doi.org/10.1016/j.ecoleon.2017.11.002

13. Michel, A, \& Hudon, M. (2015). Community currencies and sustainable development: A systematic review. Ecological Economics, 116 (1), 160-171. https://dx.doi.org/10.1016/j. ecolecon.2015.04.023

14. Ruddick, W. O., Richards, M., \& Bendell, J. (2015). Complementary currencies for sustainable development in Kenya: the case of the Bangla-Pesa. International Journal of Community Currency Research, 19 (1), 18-30.

15. Sanz, E.O. (2016). Community currency (CCs) in Spain: An empirical study of their social effects. Ecological Economics, 121 (1), 20-27.

16. Scott Cato, M., \& Suarez, A. M. (2012). Stroud Pound: A local currency to Map, Measure and Strengthen the local economy. International Journal of Community Currency Research, 16 (4), 106-115. http://dx.doi.org/10.15133/j.ijccr.2012.017

17. Seyfang, G. (2015). Community currencies and social inclusion: A critical evaluation. Working Paper EDM, No. 05-09, University of East Anglia, The Centre for Social and Economic Research on the Global Environment (CSERGE), Norwich

18. Schroeder, R. F. (2015). The financing of complementary currencies: problems and perspectives. International Journal of Community Currency Research, 19 (4), 106-113. http:// dx.doi.org/10.15133/j.ijccr.2015.011

19. Vojtovič, S. (2016). The Impact of The Structural Funds on Competitiveness of Small and Medium-Sized Enterprises. Journal of Competitiveness, 8 (4), 30-45. http://dx.doi.org/10.7441/ joc.2016.04.02

20. Wheatley, G., Younie, C., Alajlan, H., \& McFarlane , E. (2011). Calgary dollars: economic and social capital benefits. International Journal of Community Currency Research, 15 (1), 84-89. http://dx.doi.org/10.15133/j.ijccr.2011.009

21. Williams, C.C., Aldridge, T., Lee, R., Leyshon, A., Thrift, N., \& Tooke, J. (2001). Bridges into work? An evaluation of local exchange and trading schemes (LETS). Policy Studies, 22 (2), 119-134. http://dx.doi.org/10.1080/01442870127252 


\section{Contact information}

Dr. Martin Cepel, Ph.D., MBA

Faculty of Economics and Business

Paneuropean University in Bratislava

Tematinska 10, 85105 Bratislava,

Slovak Republic

Email:cepel@benzinol.com

ORCID: 0000-0002-6282-9899

doc. Ing. Aleksandr Kljucnikov, Ph.D.

University of Entrepreneurship and Law, Institute of Entrepreneurship and Marketing

Spálená 76/14, 110 00, Prague,

Czech Republic

Email:kliuchnikov@gmail.com

ORCID: 0000-0003-0350-2658

Ing. Ludmila Kozubikova, Ph.D.

Tomas Bata University in Zlin, Faculty of Management and Economics

Mostni 5139, 76001 Zlín,

Czech Republic

Email:kozubikova@utb.cz.

ORCID: 0000-0003-2017-0384

doc. RNDr. Vladimir Krajcik, Ph.D.

University College of Business in Prague

Spálená 76/14, 110 00, Prague,

Czech Republic

Email:krajcik@vso-praba.eu 